$63 ; £ 181,000$ for the agricultural researoh services, North Borneo, with a further $£ 73,625$ for the establishment of agricultural research stations ; $£ 124,755$ for the Regional Research Centre at the Imperial College of Tropical Agriculture, Trinidad, and $£ 47,459$ for horbicides research at that College; $£ 69,500$ for the Anti-Locust Research Centre and its extra-mural activities, $1960-61$; and $£ 51,009$ for the Colonial Pesticides Research Unit, Porton, 1960-63. $£ 47,892$ went to the East African Agriculture and Forestry Research Organization, $£ 33,504$ to the East African Trypanosomiasis Research Organization, and £33,283 to the East African Veterinary Research Organization; $£ 38,250$ was for trials with anti-typhoid vaceiness ; $£ 55,506$ to the Wellcome Institute for research on foot-and-mouth disease; $£ 57,295$ to the West African Rice Research Station, Rokupr, 1960-61; $£ 77.911$ for improvement and extension of agricultural facilities, Sarawak ; and $£ 33,350$ for the study of dental leishmaniasis, British Honduras.

Other major research schemes include a supplementary $£ 17.174$ to the Fish Culture Researeh Institute, Malacca ; $£ 18,503$ for research on spraying techniques and trace element deficiencies at Long Ashton; $£ 42,968$ for trachoma research in London and in The Gambia; $£ 25,920$ for the Desert Locust. Survey ; $£ 16,607$ for research into farm production costs, Kenya; and $£ 39,650$ for cereals research, Kenya, as well as $£ 21,235$ for research on coffee berry disease there, 1960-62; a supplementary $£ 20,153$ for cotton pest research, Nyasaland; $£ 22,930$ for the Joint Fisheries Development and Research Unit, Sierra Leone, 1960-62; a supplementary $£ 19,489$ for the Colonia! Microbiological Research Institute,
Trinidad; and $£ 15,126$ for the East African Virus Research Institute; $£ 27,882$ was for the Colonial Pesticides Information Service, 1960-64; $£ 16,500$ for Overseas Research Fellowships, 1960-64; and $£ 15,000$ for Colonial Medical Research Studentships, 1960-64.

Development and welfare schemes of scientific interest include $\mathfrak{1 7 , 2 3 2}$ to the Overseas Geological Surveys for age determination of rocks at the Geological Museum, University of Oxford ; $£ 25,930$ for the Desert Locust Survey ; grants totalling $£ 376,633$ to the Agricultural Department, Kenya, for the intensification of African agriculture, 1958-59; a supplementary $£ 74,974$ to Somaliland for scholarships and training abroad; $£ 182,000$ for the establishment of a Nature conservation area in the Ngorongoro Crater Highlands, Tanganyika; $£ 68,500$ for intensified control in Tanganyika of the Sudan dioch (grain. eating birds); and a supplementary £157,685 for forestry development, British Honduras. Educational grants include, besides $£ 250,000$ for a student hostel block, University College, Ibadan, Nigeria, a number of grants totalling more than $£ 169,000$ to the Nigerian College of Arts, Science and Technology ; $£ 210,000$ and $£ 233,250$ for the second and third phase, respect ively, of the expansion of general education in Lagos : $£ 308,120$ for building of schools in Northern Nigeria (with $£ 341,500$ for the development of health services) ; $\$ 368,000$ to Fourah Bay College, Sierra Leone. for constructing and equipping two halls of residence, as well as $£ 360,000$ for the construction and equipment of Freetown Teacher Training College, Sierra Leone, and miscellaneous grants totalling more than $£ 780,000$ to the University College of the West Indies.

\title{
CONTROL OF INFECTIONS
}

$\mathrm{D}^{\mathrm{L}}$ UE mainly to vaccination, fewer persons now suffer or die from such diseases as diphtheria, poliomyelitis and tuberculosis. If immunization programmes using the best available vaccines were more generally applied, the risk of infection from certain diseases could still further be reduced. Some of the problems raised by vaccination procedures are discussed in a recently published report of a European Technical Conference on the Control of Infectious Diseases through Vaccination Programmes*.

The report gives a broad picture of the legislation in force regarding vaccination in Europe. Compulsory vaccination varies considerably from one country to another; many use a mixed system in which some vaccinations are compulsory while others are not, and the general tendency is to substitute effective health education for compulsion by law. An impor. tant aspect is that of inspection and the recording of vaccinations, which makes it possible to obtain reliable data regarding their effectiveness. Generally the cost of vaccination programmes is borne by the health authorities; in some cases the cost has to be met by the patient himself, which may adversely affect the success of the campaign.

* World Health Organization. Publication No. 198: European Technical Conference on the Control of Infectious Diseases through Vaccination Programmes, Rabat, Morocco, 23-31 October, 1959. Pp. 21. (Geneva: World Health Organization; London : H.M. Stationery
Office, 1960.) 1. Swiss franc; 1s. 9d.; $0: 30$ dollars.
The report gives a brief account of the value and present state of the most important vaccinations. Although smallpox does not exist as an endemic disease in European countries, it was generally felt that it was still necessary to maintain a relatively high level of immunity in the population through continued vaccination programmes. It was agreed that $B C G$ vaccination should be considered as part of the over-all tuberculosis control programme of any country. The report discusses the types of antipolio vaccines used at present; inactivated virus vaccine and attenuated live virus vaccine, which have been successfully applied in the Soviet Union to more than twelve million persons. The use of triple vaccine against diphtheria, tetanus and pertussis is recommended, and consideration is given to thr suitability and effectiveness of many other vaccines, such as those against influenza, typhoid, paratyphoid, tularæmia, brucellosis, rabies, etc, as well as those used against quarantinable diseases (yellow fever. typhus and cholera).

After dealing with the risks and techniques of different vaccinations, the report discusses the importance they may have in the control of infectious diseases. It finally suggests models for programmes which, in the opinion of the conference, might be adopted in the various countries according to the degree of development of their health services and their own particular problems. 